\title{
FINDING THE LINK BETWEEN CSR REPORTING AND CORPORATE FINANCIAL PERFORMANCE: EVIDENCE ON CZECH AND ESTONIAN LISTED COMPANIES
}

\section{Strouhal, J., Gurvitš, N., Nikitina-Kalamäe, M., Startseva, E.}

Despite the fact that obligations to publish reports on corporate social responsibility will come into force in the European Union from 2018, an increasing number of companies are starting to implement corporate social responsibility (CSR) policy into their everyday business practices, and as a result the information of this activity is disclosed in CSR reports or within annual reports. As the disclosure of such information is currently voluntarily based, we believe that the growing popularity of CSR leads to a direct link between the sustainability of the company and its financial performance. The purpose of this paper is therefore to determine the linkage between CSR and financial performance within two countries in the CEE region - Czech and Estonia - using data from 2012 - 2013. We compare return on assets and normalized market value added of listed companies. Based on the results, we can state that the implementation of a standalone CSR report does not have any direct linkage with the financial performance of the tested companies.

Keywords: corporate social responsibility; CSR reports; sustainability; annual reports; management report; corporate governance

JEL classification: $\mathrm{G} 30$

\section{Introduction}

Corporate social responsibility (hereinafter CSR) has reached significant importance in contemporary theory as well as professional practice. The commitment to act responsibly for sustainable development of the society is mandatory for companies to create a strong corporate image as the society becomes more and more concerned about ethical, social (Mallin, 2004) and environmental (Krause, 2015) problems.

In most countries, CSR reporting is voluntary; therefore companies choose various means to disclose CSR related information, either in the form of standalone CSR reports or in the form of disclosure in the annual financial reports. The last option is most widely used as companies find it less time and effort demanding. The KPMG Survey of Corporate Responsibility Reporting conducted in 2013 revealed that there is a growing trend in CSR reporting all over the world, with the strongest growth observed in the Asia Pacific region. The survey also revealed that the Americas overtook Europe as the leading reporting region, while rates remain static in Europe and dropped in the Middle East and Africa, largely due to the number of countries with low reporting rates joining the survey for the first time (KPMG, 2013). It should also be mentioned that so far Estonia and Czech Republic have not been included into the KPMG surveys.

The reminder of this paper is organized as follows. After the linkage of the CSR topic to current trade literature, we provide a practical insight into corporate social responsibility reporting and its linkage with integrated reporting. Furthermore, we perform an analysis of CSR reporting within the Czech and Estonian markets. The listed companies 
from Prague and Tallinn Stock exchange are evaluated in order to find out the potential linkage between CSR reporting and corporate financial performance. Results are taken as a basis for concluding remarks.

\section{Literature Review}

Within the contemporary research about CSR, the following trends are widely discussed: (i) linkage between costs and benefits from CSR, and (ii) factors affecting the extent of CSR in individual jurisdictions.

Among important findings, we may cite the results of Weber (2008) who determined positive effects on company image and reputation, positive effects on employee motivation, retention and recruitment, cost savings, revenue increases from higher sales and market share and CSR-related risk reduction or management as benefits of CSR. Socially responsible entrepreneurship is the core of corporate strategy of many companies (Tyll, 2015). Goss and Roberts (2011) find out that involvement in CSR actions may decrease potential informational asymmetry and also lead to a reduction of the cost of debt.

The current management literature believes that the major factors influencing the extent of a company's CSR are: (i) profitability, (ii) size, (iii) financial leverage, (iv) market-to-book value, (v) liquidity, (vi) ownership structure (e.g. Andrikopoulos et al., 2014; Dam and Scholtens, 2012).

Ryianto and Toolsema (2007) delivered a model of possible agency conflicts between managers, shareholders and environment activists. They found out that CSR expenses may be used as an instrument for the shareholders to stipulate managers in providing more efforts to obtain information. Furthermore, Prior et al. (2008) demonstrate that CSR activities are more often undertaken by managers who practice earnings management. According to Wang and Chen (2015), CSR policies not only enhance reputation but also lead to good financial performance. The findings of Gao et al. (2015) also suggest that higher quality CSR disclosures deliver economic benefits. Similar studies have been carried out in many countries worldwide. In a study focused on Egyptian companies, Hafez (2015) found no impact of CSR on the financial performance of the banks, which was supported by a study carried out in South Africa (Chetty et al., 2015), which found that CSR activities lead to no significant differences in financial performance. It is fair to say that the evidence is mixed and doesn't provide clear answers.

Our research is focused on the study of CSR within Central and Eastern Europe. From this perspective, it should be pointed out that a majority of CSR studies are discussing developed economies and do not consider the complexity of the economic, political, social and cultural context. Brammer et al. (2007) put in evidence that socially responsible actions are more welcome in Western Europe and North America than in Central and Southern Europe, and that the nature of the CSR actions also matters in obtaining investors' approval. Doh and Guay (2006) explain that economic conditions, cultural inheritance, political grounds and government decisions influence the expectations of the users in general and the stakeholders' ones in particular, regarding the extent and the domains of the CSR. These results might be confirmed by Salaber (2007) who believes that investors' perception about a company is strongly or weakly committed to CSR goals depends on the national culture.

The authors believe that the growing popularity of CSR has led to the direct link between the sustainability of a company and its financial performance. As CSR reporting 
is seen as a step towards the successful and sustainable business of each company, it should have a direct impact on the financial performance of companies.

A review of the past literature shows that performance measurement is a difficult and complex phenomenon and evaluators lack widely recognized performance measurement methods. There also seems to be no agreement on which method of financial performance measurement performs better than others. Performance measurement methods used by the authors in the present research have been selected to suit the researchers' aims and objectives. By using alternative financial performance measures (such as return on equity, growth in revenues, employee productivity) in the future the authors intend to extend the current research.

\section{CSR Reporting in the European Union Context}

In December 2014, an update of accounting Directive 2013/34/EU on Disclosure of Non-Financial and Diversity Information by Certain Large Companies came into force. EU member countries have to transpose the requirements of this directive into national legislatures. Based on the Brussels view, first company reports including such information shall be published in 2018 covering the financial year 2017-2018.

As this topic is relatively new for the area of Central and Eastern Europe, it would be vital to mention within this part the requirements of this accounting directive amendment.

According to the new article 19a, it is expected that large "public-interest entities" exceeding the average number of 500 employees during the financial year shall prepare so called "non-financial statement". Within this report there, these companies have to present information necessary for an understanding of the company's development, performance, position and impact of its activity, relating to, as a minimum, environmental, social and employee matters, respect for human rights, anti-corruption and bribery matters, including (EUR-Lex (2015a):

(a) a brief description of the undertaking's business model;

(b) a description of the policies pursued by the undertaking in relation to those matters, including due diligence processes implemented;

(c) the outcome of those policies;

(d) the principal risks related to those matters linked to the undertaking's operations including, where relevant and proportionate, its business relationships, products or services which are likely to cause adverse impacts in those areas, and how the undertaking manages those risks;

(e) non-financial key performance indicators relevant to the particular business.

The non-financial statement shall also include references to, and additional explanations of, amounts reported in the annual financial statements.

According to the directive, it is possible to prepare a "non-financial statement" as a separate report or as a part of a "management report".

Based on article 19, a management report shall include a fair review of the development and performance of the undertaking's business and of its position, together with a description of the principal risks and uncertainties that it faces. To the extent necessary for an understanding of the undertaking's development, performance or position, the 
analysis shall include both financial and, where appropriate, non-financial key performance indicators relevant to the particular business, including information relating to environmental and employee matters. In providing the analysis, the management report shall, where appropriate, include references to, and additional explanations of, amounts reported in the annual financial statements. It contains an indication of:

(a) the undertaking's likely future development;

(b) activities in the field of research and development;

(c) the information concerning acquisitions of own shares;

(d) the existence of branches of the undertaking; and

(e) in relation to the undertaking's use of financial instruments and where material for the assessment of its assets, liabilities, financial position and profit or loss:

(i) the undertaking's financial risk management objectives and policies, including its policy for hedging each major type of forecasted transaction for which hedge accounting is used; and

(ii) the undertaking's exposure to price risk, credit risk, liquidity risk and cash flow risk. The management report of large companies shall also include corporate governance statement. It shall contain at least the following information:

(a) a reference to the following, where applicable:

(i) the corporate governance code to which the undertaking is subject,

(ii) the corporate governance code which the undertaking may have voluntarily decided to apply,

(iii) all relevant information about the corporate governance practices applied over and above the requirements of national law,

(b) where an undertaking departs from a corporate governance code, an explanation by the undertaking as to which parts of the corporate governance code it departs from and the reasons for doing so; where the undertaking has decided not to refer to any provisions of a corporate governance code, it shall explain its reasons for not doing so;

(c) a description of the main features of the undertaking's internal control and risk management systems in relation to the financial reporting process;

(d) the information required by Directive 2004/25/EC on takeover bids;

(e) unless the information is already fully provided for in national law, a description of the operation of the shareholder meeting and its key powers and a description of shareholders' rights and how they can be exercised;

(f) the composition and operation of the administrative, management and supervisory bodies and their committees; and

(g) a description of the diversity policy applied in relation to the undertaking's administrative, management and supervisory bodies with regard to aspects such as, for instance, age, gender, or educational and professional backgrounds, the objectives of that diversity policy, how it has been implemented and the results in the reporting period. If no such policy is applied, the statement shall contain an explanation as to why this is the case. 


\section{Research Design}

The aim of this research is to find out whether there is a linkage between CSR reporting and financial performance and whether the companies producing standalone CSR reports show better financial performance. The authors used data obtained from the annual financial reports of companies for the year 2012 and 2013. The authors believe that the listed companies tend to be more advanced in CSR reporting in comparison with non-listed companies, therefore 15 companies listed on the Nasdaq OMX Baltic (Tallinn market) and 23 companies, whose shares are traded on the Prague Stock Exchange as of May 2014 were included into the research.

By calculating accounting and market based ratios of the companies' current financial performance measures, the authors examine the existence of linkage between CSR reporting and companies' financial performance. Return on assets (ROA) is an accounting based indicator of how profitable a company is relative to its total assets. It has been widely used in comparative analyses (Machek et al., 2013). Calculated by dividing a company's annual income before tax by its average total assets, ROA is displayed as a percentage. Market value added (MVA) is the most popular market based approach to measure performance. MVA is calculated as the market evaluation of the company minus invested capital. Market evaluation of the company is calculated as the number of shares outstanding multiplied by the share market price on 31 December 2013. Invested capital equals to the amount of the book value of stockholders' equity on 31 December 2013.

\section{Results}

Normalized $\triangle \mathrm{MVA}$ is a specific type of MVA calculation displayed as a percentage. The intention to use this ratio in research is that these normalized values allow the comparison of corresponding normalized values for different companies in a way that eliminates the effects of certain gross influences. To calculate the normalized $\triangle \mathrm{MVA}$, we used the following equation:

$$
\text { Normalized } \Delta \mathrm{MVA}_{t}=\left(\mathrm{MVA}_{\mathrm{t}}-\mathrm{MVA}_{t-1}\right) / I_{t-1}
$$

where MVA $t$ is MVA at the end of the period 1 (in our example at the end of the year 2013), MVA $_{t-1}$ is MVA at the end of the period 0 (in our example at the end of the year 2012), and $I_{t-1}$ is the invested capital at the end of the period 0 (in our example at the end of the year 2012).

CSR reporting research results of publicly listed companies are presented in Table 1.

Table 1 | CSR Reporting by the Estonian and Czech listed for the year 2013

\begin{tabular}{|l|c|c|}
\hline Type of disclosures & Estonia & Czech Republic \\
\hline Standalone CSR reports & 5 & 5 \\
\hline CSR related information disclosures in the annual report & 12 & 15 \\
\hline Absence of CSR related information & 1 & 3 \\
\hline
\end{tabular}

Source: Authors 
Table 2 | Accounting based performance measure ROA and existence of standalone CSR report for companies listed on the Prague Stock Exchange for 2013

\begin{tabular}{|c|c|c|}
\hline Company's core business & ROA (\%) & $\begin{array}{l}\text { Standalone } \\
\text { CSR report }\end{array}$ \\
\hline Fixed-odds betting operator & 22.59 & no \\
\hline Production of tobacco products & 13.99 & no \\
\hline $\begin{array}{l}\text { Production and distribution of technical gas, heat, water, wastewater } \\
\text { treatment, distribution of electricity, air-conditioning }\end{array}$ & 11.74 & no \\
\hline Sale of telecommunication services & 9.49 & yes \\
\hline $\begin{array}{l}\text { Financial enterprise, business participation in the line of tanning and } \\
\text { chemical production, energy services, real estate property rental }\end{array}$ & 6.98 & no \\
\hline Financial services - insurance & 6.21 & no \\
\hline Advisory in the field of entrepreneurship and management & 5.49 & no \\
\hline Sale of electricity, & 5.45 & yes \\
\hline Operation of photovoltaic power plants & 3.69 & no \\
\hline Sport facilities operating & 3.30 & no \\
\hline Banking facilities & 2.13 & no \\
\hline $\begin{array}{l}\text { Sanitary department, road maintenance, waste disposal, waste dumps } \\
\text { maintenance, scrap separation }\end{array}$ & 1.86 & no \\
\hline $\begin{array}{l}\text { Design, construction and lease out of logistics complexes and semi- } \\
\text { industrial parks in the region of Central and Eastern Europe }\end{array}$ & 1.60 & no \\
\hline Production of nonwoven textiles & 1.13 & no \\
\hline Non-banking financing market in the Central and Eastern Europe region & 1.03 & no \\
\hline Banking facilities & 0.18 & no \\
\hline Production of beer, malt, non-alcoholic beverages and other production & -0.82 & no \\
\hline Production of alcoholic beverages & -1.14 & yes \\
\hline Crude oil processing, production of petrochemical products & -2.66 & yes \\
\hline $\begin{array}{l}\text { Owning and operating of commercial TV stations in Central and Eastern } \\
\text { Europe }\end{array}$ & -14.43 & no \\
\hline Chemical production & -27.80 & no \\
\hline $\begin{array}{l}\text { Mineral exploration and prospecting, scientific and research programs, } \\
\text { technologies development programs }\end{array}$ & -58.18 & no \\
\hline Searching, mining and sale of pit-coal & -67.97 & yes \\
\hline
\end{tabular}

Source: Authors 
Recent research indicates that standalone CSR report preparation is not extensively used by companies. The research noted that only a few companies from both countries prepare standalone CSR reports, however most companies present CSR related information on their websites.

Table 2 presents the ROA ratios of 23 companies listed at Prague Stock Exchange ordered by the value of ROA in 2013 (descending order). The table also indicates whether companies prepare standalone CSR reports.

The results clearly demonstrate that companies with the highest value of ROA $(22.59 \%$ and $13.99 \%)$ are characterized by the absence of standalone CSR reports. However, two companies (Searching, mining and sale of pit-coal; Crude oil processing, production of petrochemical products) with a high level of CSR disclosure have low values of ROA ( $-67.97 \%$ and $-2.66 \%)$. Consequently, a higher level of CSR disclosure does not increase financial performance (as measured by ROA).

Table 3 presents the ROA ratios of 15 companies listed at Nasdaq OMX Baltic (ordered by ROA, descending order).

Table 3 | Accounting based performance measure ROA and existence of standalone CSR report for companies listed at Nasdaq OMX Baltic (Tallinn market) for 2013

\begin{tabular}{|l|c|c|}
\hline Company's core business & ROA (\%) & $\begin{array}{c}\text { Standalone } \\
\text { CSR report }\end{array}$ \\
\hline Casino operations and hotel management & 27.47 & no \\
\hline Production and sale of women's lingerie & 23.07 & no \\
\hline Property development, services, construction & 12.59 & no \\
\hline Water supply, wastewater collection and treatment & 12.18 & yes \\
\hline Electrical engineering and telecommunication & 7.90 & no \\
\hline Wholesale and resale of goods & 6.90 & no \\
\hline Construction & 4.80 & yes \\
\hline Construction and engineering & 4.41 & no \\
\hline Maritime transportation & 2.72 & yes \\
\hline Food \& Beverage & 1.64 & yes \\
\hline Media and publishing & 1.37 & no \\
\hline Clothing retail & 1.26 & yes \\
\hline Property development & 0.38 & no \\
\hline Real estate development & -2.68 & no \\
\hline Production of fiberboards & -4.65 & no \\
\hline
\end{tabular}

Source: Authors 
Table 4 | Market based performance measure normalized $\triangle$ MVA and existence of standalone CSR report for companies listed on the Prague Stock Exchange for 2013

\begin{tabular}{|c|c|c|}
\hline Company's core business & $\begin{array}{l}\text { Normalized } \\
\text { MVA (\%) }\end{array}$ & $\begin{array}{l}\text { Standalone } \\
\text { CSR report }\end{array}$ \\
\hline Fixed-odds betting operator & 168.33 & no \\
\hline Searching, mining and sale of pit-coal & 37.93 & yes \\
\hline Production of nonwoven textiles & 36.42 & no \\
\hline $\begin{array}{l}\text { Owning and operating of commercial TV stations in Central and } \\
\text { Eastern Europe }\end{array}$ & 34.12 & no \\
\hline Chemical production & 30.41 & no \\
\hline Banking facilities & 20.97 & no \\
\hline Sport facilities operating & 16.13 & no \\
\hline Financial services - insurance & 8.14 & no \\
\hline $\begin{array}{l}\text { Sanitary department, road maintenance, waste disposal, waste } \\
\text { dumps maintenance, scrap separation }\end{array}$ & 4.85 & no \\
\hline Operation of photovoltaic power plants & 2.89 & no \\
\hline $\begin{array}{l}\text { Production and distribution of technical gas, heat, water, } \\
\text { wastewater treatment, distribution of electricity, air-conditioning }\end{array}$ & 2.76 & no \\
\hline Banking facilities & 1.93 & no \\
\hline Crude oil processing, production of petrochemical products & -0.20 & yes \\
\hline Production of tobacco product & -3.96 & no \\
\hline $\begin{array}{l}\text { Non-banking financing market in the Central and Eastern Europe } \\
\text { region }\end{array}$ & -7.91 & no \\
\hline $\begin{array}{l}\text { Designs, construction and leases out of logistics complexes and } \\
\text { semi-industrial parks in the region of Central and Eastern Europe. }\end{array}$ & -9.78 & no \\
\hline Sale of telecommunication services & -15.52 & yes \\
\hline $\begin{array}{l}\text { Financial enterprise, business participation in the line of tanning } \\
\text { and chemical production, energy services, real estate property } \\
\text { rental }\end{array}$ & -18.30 & no \\
\hline Advisory in the field of entrepreneurship and management & -29.36 & no \\
\hline Sale of electricity & -37.15 & yes \\
\hline
\end{tabular}

Source: Authors

It should be noted that two companies with the highest value of ROA $(27.47 \%$ and $23.07 \%$ ) are characterized by absence of standalone CSR reports. However, two companies (Maritime transportation and Food \& beverage) with a high level of CSR disclosure have low values of ROA $(2.72 \%$ and $1.64 \%)$. 
Table 4 presents the normalized $\triangle$ MVA ratios of 23 companies listed on the Prague Stock Exchange (in order of decreasing ratio value); three companies were excluded from the research as they entered the stock exchange in the middle of year 2013.

The company with the highest normalized $\triangle$ MVA $(168.33 \%)$ is characterized with the absence of a standalone CSR report. Most of the other companies with the high value of normalized $\triangle \mathrm{MVA}$ ratio are characterized by absence of standalone CSR reports as well. However, the company with the highest level of CSR disclosure has the lowest value of normalized $\triangle$ MVA $(-37.15 \%)$.

Table 5 presents the normalized $\triangle$ MVA ratios of companies listed on the Nasdaq OMX Baltic (in order of decreasing ratio value).

Table 5 | Market based performance measure normalized $\triangle$ MVA and existence of standalone CSR report for companies listed on the Nasdaq OMX Baltic (Tallinn market) for 2013

\begin{tabular}{|l|c|c|}
\hline Company's core business & $\begin{array}{c}\text { Normalized MVA } \\
(\%)\end{array}$ & $\begin{array}{c}\text { Standalone CSR } \\
\text { report }\end{array}$ \\
\hline Water supply and wastewater collection and treatment & 60.78 & yes \\
\hline Property development & 46.62 & no \\
\hline Construction & 15.41 & yes \\
\hline Real estate development & 12.02 & no \\
\hline Production of fiberboards & 7.85 & no \\
\hline Food \& Beverage & 4.17 & yes \\
\hline Casino operations and hotel management & 3.35 & no \\
\hline Media and publishing & 3.00 & no \\
\hline Maritime transportation & 0.42 & yes \\
\hline Wholesale and resale of goods & -2.24 & no \\
\hline Clothing retail & -7.00 & yes \\
\hline Production and sale of women's lingerie & -6.78 & no \\
\hline Electrical engineering and telecommunication & -24.00 & no \\
\hline Construction and engineering & -26.42 & no \\
\hline Property development, services, construction & -129.00 & no \\
\hline
\end{tabular}

Source: Authors

The company with the highest normalized $\triangle$ MVA $(60.78 \%)$ has prepared a standalone CSR report. The other companies with the higher values of normalized $\triangle \mathrm{MVA}$ ratio are thus characterized by absence of standalone CSR reports.

We also perform a one-way analysis of variance (ANOVA) with independent samples to test the equality of means of ROA and MVA for the two categories (using a binary 
variable determining whether a company performs standalone CSR reporting). The null hypothesis is that the means are equal for the two groups.

The descriptive statistics are presented in table 6.

Table 6 | One-way ANOVA test of equality of means: Descriptive statistics

\begin{tabular}{|l|c|c|c|c|c|}
\hline \multirow{2}{*}{ CSR reporting } & \multirow{2}{*}{ Sample size } & \multicolumn{2}{|c|}{ Mean } & \multicolumn{2}{c|}{ Standard deviation } \\
\cline { 3 - 6 } & & ROA & MVA & ROA & MVA \\
\hline Yes & 10 & -3.42 & 6.53 & 23.12 & 28.88 \\
\hline No & 28 & 1.98 & 5.60 & 15.64 & 47.41 \\
\hline
\end{tabular}

Source: Authors

According to the ANOVA test, the F statistics is 0.01 for ROA (not significant, p-value of 0.90 ) and 0.59 for MVA (not significant, p-value of 0.44 ). We don't reject the null hypotheses on equality of means, so the hypothesis on no effect of CSR reporting on performance may be valid. However, it should be noted that the sample size is too small to make predictions about the population. On the other hand, all listed companies have been evaluated, so the only possibility to extend the data sample is to include companies from other countries or to perform a longitudinal analysis.

\section{Discussion and Conclusion}

The results of research indicate there was no direct relationship between the act of presenting standalone CSR reports and financial performance of companies listed on the Prague Stock Exchange and Nasdaq OMX Baltic. Callan and Thomas (2009) confirmed that "For some time, researchers have been investigating the relationship between a firm's corporate financial performance (CFP) and its corporate social performance (CSP)." However, the existing studies as well as our paper provide quite controversial results on such a relationship.

As mentioned within a practical part of this paper, the information about corporate social responsibility is currently voluntarily disclosed by the companies and a fresh start for listed companies is expected for 2018. However, it should be mentioned that CSR reporting in both countries is quite popular in the form of disclosures to annual financial statements as this option is less time and effort-consuming. This may be explained by the fact that more and more information about CSR initiatives are available in Czech and Estonia and that more CSR-related events are occurring during the last few years.

The authors are aware that the study has several limitations. The performance was only compared by two financial ratios. And even though we didn't find any statistically significant effect of CSR reporting on performance, the sample size is fairly small to make predictions about the parameters of the population (that is to say, all listed companies in the world). Other possible lurking and mediating variables, such as firm size or industry affiliations, certainly determine the profitability of companies.

For the future research, we expect to broaden the scope and investigate the existence of relationship between CSR reporting and financial performance among companies from multiple countries, as well as using various market-based and accounting based ratios. 


\section{References}

Andrikopoulos, A., Samitas, A., \& Bekiaris, M. (2014). Corporate social responsibility reporting in financial institutions: Evidence from Euronext. Research in International Business and Finance, 32, 27-35.

Brammer, S., Millington, A., \& Rayton, B. (2007). The Contribution of Corporate Social Responsibility to Organizational Commitment. International Journal of Human Resources Management, 18(10), 1701-1719.

Callan, S. J., \& Thomas, J. M. (2009). Corporate financial performance and corporate social performance: an update and reinvestigation. Corporate Social Responsibility and Environmental Management, 16, 61-78.

Chetty, S., Naidoo, R., \& Seetharam, Y. (2015). The impact of corporate social responsibility on firms' financial performance in South Africa. Contemporary Economics, 9(2), 193-214.

Dam, L., \& Scholtens, B. (2012). Does Ownership Type Matter for Corporate Social Responsibility? Corporate Governance: An International Review, 20(3), 233-252.

Doh, J. P., \& Guay, T. R. (2006). Corporate social responsibility, public policy, and NGO activism in Europe and the United States: An institutional-stakeholder perspective. Journal of Management Studies, 43(1), 47-73.

EUR-Lex (2015a). Directive 2014/95/EU of the European Parliament and of the Council of 22 October 2014 amending Directive 2013/34/EU as regards disclosure of non-financial and diversity information by certain large undertakings and groups. Retrieved August 10, 2015 from: http://eur-lex.europa.eu/legal-content/EN/TXT/?uri=CELEX:32014L0095

EUR-Lex (2015b). Directive 2013/34/EU of the European Parliament and of the Council of 26 June 2013 on the annual financial statements, consolidated financial statements and related reports of certain types of undertakings, amending Directive 2006/43/EC of the European Parliament and of the Council and repealing Council Directives 78/660/EEC and 83/349/ EEC. Retrieved August 10, 2015 from: http://eur-lex.europa.eu/legal-content/EN/ TXT/?uri=celex:32013L0034.

Gao, F., Dong, Y., Ni, C., \& Fu, R. (2015). Determinants and Economic Consequences of Non-financial Disclosure Quality, European Accounting Review. Article in press.

Goss, A., \& Roberts, G. S. (2011). The Impact of Corporate Social Responsibility on the Cost of Bank Loans. Journal of Banking and Finance, 35(7), 1794-1810.

Hafez, H. M. (2015). Corporate social responsibility and financial performance: An empirical study on Egyttian banks. Corporate Ownership and Control, 12(2), 107-127.

KPMG (2013). The KPMG Survey of Corporate Responsibility Reporting 2013. Retrieved August 10, 2015 from: http://www.kpmg.com/AU/en/IssuesAndInsights/ArticlesPublications/ Documents/corporate-responsibility-reporting-survey-2013.pdf.

Krause, J. (2015). The Potential of an Environmentally Friendly Business Strategy-Research from the Czech Republic. International Journal of Engineering Business Management, 7.

Machek, O., Brabec, M., \& Hnilica, J. (2013) Measuring Performance Gaps Between Family and Non-Family Businesses: A Meta-Analysis of Existing Evidence. International Academic Research Journal of Business and Management, 2(3).

Mallin, C. (2004). Corporate Governance. Oxford: Oxford University Press.

Prior, D., Surroca, J., \& Tribo, J. (2008). Are Socially Responsible Managers Really Ethical? Exploring the Relationship between Earnings Management and Corporate Social Responsibility. Corporate Governance, 16(3), 160-177. 
Riyanto, Y. E., \& Toolsema, L. A. (2007). Corporate Social Responsibility in a Corporate Governance Framework, working paper. Available from: http://papers.ssrn.com/sol3/ papers.cfm?abstract_id=987962.

Salaber, J. (2007). The Determinants of Sin Stock Returns: Evidence on the European Market, working paper, University of Bath School of Management.

Tyll, L. (2015). Podniková strategie (Corporate strategy). Prague: C. H. Beck.

Wang, Y.-S., \& Chen, Y.-J. (2015). Corporate social responsibility and financial performance: Event study cases. Journal of Economic Interaction and Coordination. Article in press.

Weber, M. (2008). The Business Case for Corporate Social Responsibility: A Company-level Measurement Approach for CSR. European Management Journal, 26, 247-261.

\section{Authors}

\section{Dr. Jiří Strouhal}

Associate Professor

Department of Strategy, Faculty of Business Administration, University of Economics Prague W. Churchill Square 4, 13067 Prague 3, Czech Republic

jiri.strouhal@vse.cz

\section{Dr. Natalja Gurvitš}

Associate Professor

Department of Accounting, Tallinn School of Economics and Business Administration Akadeemia tee 3, 12618 Tallinn, Estonia

natalja.gurvits@ttu.ee

\section{Monika Nikitina-Kalamäe}

\section{Lecturer}

Department of Accounting, Tallinn School of Economics and Business Administration Akadeemia tee 3, 12618 Tallinn, Estonia

monika.nikitina-kalamae@ttu.ee

\section{Emilia Startseva}

Ph.D. student

Department of Accounting, Tallinn School of Economics and Business Administration Akadeemia tee 3, 12618 Tallinn, Estonia

emilia.startseva@ttu.ee

This paper is one of the research outputs of the project IGA VŠE F3/2/2014. 